Araştırma Makalesi

Research Article
Gönderim Tarihi/Submission Date: 05.05.2020

Kabul Tarihi/Accepted Date: 25.05.2020

DOI: $10.46250 /$ kulturder.732751

Kültür Araştırmaları Dergisi, 2020, Sayı: 5, s. 89-111.

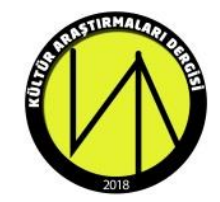

\title{
ROMAN DILINI SINEMAYA YAKLAŞTIRAN GIZLI AKTÖR: EDIMSÖZLER
}

The Hidden Actor Which Approximate Novel Language to Cinema: Illocutions

\section{Cem KESER*}

\section{ÖZET}

İngiliz dilbilimci filozof Austin'in ortaya koyup başka bir dilbilimci J. R. Searle'ün geliştirdiği söz edimleri kuramının hedefi 'günlük dili' araştırmaktır. Edim, Türk Dil Kurumu'nun tanımına göre, "Yapılmış, gerçekleşmiş iş, amel, fiil” olan edimleri tasniflemesi bakımından dilbilim çalışmalarında farklı bir yaklaşımın gelişmesine sebebiyet vermiştir. Bu yaklaşım dili sadece olgular bünyesinde algılayan ve çözümleyen mantıkçı pozitivistlere bir tepki olarak gelişmiş ve günlük hayatta konuştuğumuz dili incelemeye başlamıştır. Söz edimleri kuramının en belirgin özelliği betimleyici ifadelerle edimsel cümleleri bir kural mekanizması oluşturarak ayırması olmuştur. Söz Edimleri Kuramı başlığı altında yapılan çalışmalar, ilk etapta sadece insanlar arasındaki dilsel iletişimi araştırırken daha sonraları edebî metinleri de araştırma malzemesi hâline getirmiştir. Son dönemlerde çokça tartışılan bir başka konu ise sinemanın edebiyat ile ilişkisi ve bu ilişkiye bağlı olarak roman dilinin sinemaya yaklaştığı iddiasıdır. Sinema dilinin oyuncu eylemlerine dayalı olduğu kabulüyle sinemayı besleyen bir kaynak olarak edebiyat ürünlerinin edimsözler üzerinden incelenmesi, bu iddialara cevap verebilecek somut veriler sağlamaktadır. Çalışma, bu iddia çerçevesindeki soruların cevabını aramaktadır. Makalede Sodom ve Gomore, Kuyucaklı Yusuf, Aylak Adam, Tehlikeli Oyunlar ve Kırmızı Saçlı Kadın adlı eserlerdeki edimsözlerin varlığı ve kullanımı üzerine çalışılmıştır. Incelememizin sonucunda ilk baskısı 1928 yılında yapılan ve 295 sayfa olan Sodom ve Gomore'nin edimsöz sayısı 922 çıkarken ilk baskısı 1937 yılında yapılan ve toplam 220 sayfa olan Kuyucaklı Yusuf'ta bu sayı 1016'dır. Bunun dışında 1959 yılında ilk baskısı yapılan ve 190 sayfa olan Aylak Adam romanında ise edimsözler 1345 adet çıkmıştır. İncelediğimiz beş roman içerisinde edimsözlerin en fazla çıktığı eser Tehlikeli Oyunlar'dır. Bu romanda 2345 adet edimsöz çıkarken 190 sayfalık Kırmızı Saçlı Kadın romanımızda toplam edimsöz sayısı 820'dir. Ek olarak Searle'ün tasnifine göre yaptığımız edimsöz araştırmasında bütün romanlarda sayıları en fazla çıkan edimsözlerin kesinleyiciler ve yönelticiler olduğu görülmüştür.

Anahtar Sözcükler: Dilbilim, Gündelik Dil, Söz Edimleri, Edimsözler, Saussure, Austin, Searle, Levent Aysever.

\footnotetext{
* Yüksek Lisans Öğrencisi. İstanbul Kültür Üniversitesi, Lisansüstü Eğitim Enstitüsü, Türk Dili ve Edebiyatı Anabilim Dalı-istanbul. E-posta: cem_3862@hotmail.com. ORCID ID: 0000-00024107-4255.
}

This article was checked by Turnitin. 


\section{ABSTRACT}

The speech-act theory, which was proposed by English linguist philosopher Austin and improved by J. R. Searle, has provided the progress of a different approach in linguistics. This approach has evolved in terms of transforming the daily language into a research ingredient and sorting out acts that are defined by the Turkish Language Society as "work intention, an action which have been done or occurred." The language of this different approach has evolved as a reaction facing logician positivists, who perceive and analyse language within the phenomenon. It has begun to examine the spoken word in daily life. The most typical characteristic of the speech-act theory is its separation of descriptive expressions from performative sentences via building a rule mechanism. While the studies which were conducted under the title of speech-act theory investigated at first, the linguistic communication only between humans, they later became the research material of the literary texts as well. Another topic of discussion has recently been the gets approach to the cinema. Admitting the fact that the place of the actions in the performer action-oriented cinema world cannot be ignored, we think that research about the literature as a source that obtains nourishment from cinema in terms of actuality will bring a separate aspect to this claim. This study explores the responses to the questions on this claim. In this article, it was studied on the existence and utilization of illocutions in Sodom ve Gomore, Kuyucaklı Yusuf, Aylak Adam, Tehlikeli Oyunlar and Kırmızı Saçlı Kadın. 922 illocutions were determined in Sodom ve Gomore. Although nine years have passed between the Sodom ve Gomore (number of pg.295) and Kuyucaklı Yusuf (number of pg. (221), 1116 illocutions were found in Kuyucaklı Yusuf. Aylak Adam (number of pg. 190) has 1345 illocutions, and also, Tehlikeli Oyunlar has 2599 illocutions. It's the highest number among the novels. Lastly, there are 820 illocutions in Kırmızı Saçlı Kadın (number of pg.195). It seems to be less than other novels, but considering the number of pages, Kırmızı Saçlı Kadın has an important illocution quantity. According to Searle's classification in our illocution study, we observed that the most frequently encountered illocutions are assertives and directives.

Key Words: Linguistic, Daily Language, Speech act, Illocutions, Saussure, Austin, Searle, Levent Aysever

\section{Giriş}

Insanlığın birbiriyle iletişimi ve yaşamdaki sosyal, siyasal ya da kültürel tüm yapıların oluşması dile bağlıdır. Dil hayatın ana öznesidir. İnsan doğayı dil aracılığıyla tanır ya da tanılar. Türdeşlerimizle kurduğumuz sosyal iletişimin yapı taşı olan dildeki edimleri incelemek dile bağlı olarak gelişen edebiyat ve sinemanın arasındaki ilişkiye farklı bir pencereden bakılmasını sağlayabilir. Sinemanın dile olan bağımlıı̆̆ını hatta dil gibi olduğunu James Monaco şöyle belirtir: "Sinema bir dil değildir ama dil gibi olması nedeniyle, dil araştırmalarında kullandığımız yöntemlerin bazılarını 
sinema araştırmalarına uygulamak yararlı olabilir." (2000: 153). Monaco'nun görüşünden hareketle, edimsel düşünceye dayalı bir dilbilim kuramının roman türü içinde incelenmesinin, sinema-edebiyat yakınlaşması konusuna yararlı bir yaklaşım sağlayabilir.

Sinema sektörü romanlardan uyarlama yaparak edebiyattan malzeme alır ve sonuç olarak romandan uyarlama birçok sinema filmi izleyiciye sunulur. Buradaki uyarlama işleminin içeriğine kısaca değinmek gerekir. Çünkü edebiyatla sinemanın buluştuğu noktalardan biri de uyarlama aşamasıdır. Yönetmen edebî eseri okurken ondan bir senaryo çıkarmaya bakar. Edebî metin senaryoya çevrilirken çevirim senaryosu aşamasından geçer (Yüce, 2005). Bu aşamada yapılan tüm tasarımların öykü içerisindeki kişilere, olaylara ya da yere göre hazırlanması gerekir. Ünlü yönetmen Sergey Eisenstein bu süreçle ilgili şunları belirtir: "Aksiyonun tek tek her durumunun, anının planlara ayrılarak belirtilmesiyle yalnızca heyecansal izlenimi güçlendirmekle kalmaz, olayların özgün yorumunu da yaparız. Alıcının her yeni konumu seyirciyi olaylara belirli tek bir yerden baktırır. Bu arada senaryonun akışı içinde, kişilerin mekân içinde aralarındaki genel ilişkilerini, hareketlerinin yönünü, zaman ve ritim birliğini, vb. korumak da gerekmektedir" (1999: 88). Yönetmenin belirttiği kişilerin genel ilişkilerinin ve hareketlerinin yönü önemli bir yerde durmaktadır. Roman ya da öyküdeki karakterlerin genel ilişkileri ve hareketlerinin yönü edimsellik başlığı altında değerlendirilip bu türlerdeki edimsözlerin varlığının tespit edilmesi sinema ile edebiyat arasında daha önce adı konulmamış bir kanalın açılmasına sebebiyet verebilir. Ek olarak, sinemaya yakınlaşan edebî metinlere, özellikle romana, bu açıdan yaklaşmak 18 ya da 19. yüzyıl okuyucusundan farklı olarak sinemayı gören 20 ve 21. yüzyıl okuyucusunun yazar seçiminin ne yönde etkilendiğine farklı bir açıyla bakmaya zemin hazırlayabilir. Bu hususlardan hareketle makalemizde sinema ve edebiyat yakınlaşması konusuna Söz Edimleri Kuramı üzerinden incelediğimiz romanlarla yeni bir bakış açısı geliştirmeyi amaçladık.

Sinematografi bir filmde sahnelerin arka arkaya akmasını sağlayan makineye verilen ad ise söz de dünyada hareketi sağlayan dilsel mekanizmadır. Bu bakımdan bir edebî üründe, edimsözlerin yoğun olarak kullanılmasının metine anlatımsal hareketi kazandıran önemli bir unsur olduğu kanaatindeyiz. Buradan hareketle makalemizde, roman-sinema ilişkisinin ya da roman dilinin senaryoya yakınlaşmasının "dilbilimsel" zeminini bulmaya çalıştık. İddiamızı somutlamak için Sodom ve Gomore (Karaosmanoğlu, 2017), Kuyucaklı Yusuf (Ali, 2015), Aylak Adam (Atılgan, 2017), Tehlikeli Oyunlar (Atay, 2018) ve Kırmızı Saçlı Kadın (Orhan, 2016) roman- 
larındaki edimsöz varlıklarını inceledik. İncelememizde belirttiğimiz romanların içinde bulunan tüm cümleleri Searle'ün edimsöz tasnifine göre (kesinleyiciler, yönelticiler, yükleyiciler, dışavurucular ve bildirgeler) gruplara ayırarak sayısal bir veri elde ettik. Göstermek amacında olduğumuz bir başka konu, çalışmamız özelindeki romanların edimsöz sayısındaki gelişme olunca, erken Cumhuriyet döneminden başlayıp günümüz romanına uzanan bir kronolojik sıra yaratmamız gerekiyordu. Bu yüzden kronolojik sıranın başına Yakup Kadri'nin Sodom ve Gomore'sini koyduk.

İncelememize konu olan romanları seçerken hâlihazırda görselleştirilmiş romanların içinden çıkarılacak edim varlığı da merakımızı cezbeden bir diğer unsurdu. Buradan hareketle Kuyucaklı Yusuf ve Tehlikeli Oyunlar eserlerine ayrı bir parantez açmak zorunda olduğumuzu düşünüyoruz. Bu iki eser sinemaya ve tiyatroya uyarlanmıştır. Tehlikeli Oyunlar'ın tiyatrosu ${ }^{1}$ çeşitli tiyatro sahnelerinde hâlâ gösterimdedir. Kuyucaklı Yusuf ise Feyzi Tuna'nın yönetmenliğinde 1985 yılında sinemaya uyarlanmıştır. Romanları seçerken ölçüt aldığımız son nokta ve makalemizdeki bir diğer amacımız ise basımının üzerinden yıllar geçen, Kuyucaklı Yusuf, Aylak Adam ya da Tehlikeli Oyunlar'ın üzerindeki ilginin günümüzde neden bu kadar arttığı ve roman dilini sinemaya yaklaştırdığını düşündüğümüz edimsözlerin bu ilgide payının olup olmadığını tespit etmektir. Kırmızı Saçlı Kadın romanını seçmemizin nedeni ise Nobel Edebiyat Ödülü'nü almış bir yazarın roman kurgusunda edimsözlerin ağırığını tespit etmektir.

\section{Söz Edimleri Kuramı}

18. ve 19. yüzyıllar modern anlamdaki dilbilim çalışmalarının başlangıç dönemi olarak kabul edilir (Yozgat, 2018: 36). 20. yüzyıla gelindiğindeyse dil tek başına incelenen bir çalışma nesnesi olarak görülür. Hiç şüphesiz bu yüzyıla damgasını vuran dilbilimci Saussure'dür. Saussure'ün ortaya attığı göstergebilim yani dilin bir göstergeler dizgesi olarak tanımlanması (1998: 46) çağdaş dilbilimin önünü açar ve modern dilbilimle ilgili pek çok temel kavramın da oluşmasına zemin hazırlar (Yozgat, 2018: 36). Saussure, dili bir göstergeler dizgesi olarak ele alırken aynı zamanda bir bilim tasarlamak istemektedir. Saussure, toplumsal ruhbilimine bunun sonucu olarak da genel ruhbilimine bağlanacak bir bilim tasarlarken buna göstergebilim adını vermiştir (1998: 46). Sauusure "Genel Dilbilim Dersleri" eserinde eski dilbilgisi yaklaşımlarının yalnızca "eşsüremli" olguları incelediğini aktarır (1998: 131). Ünlü dilbilimci “artsüremliliği” yani dildeki evrim aşamasını da hesaba katarak dilbilimine yeni ve yapısalcı bir yakla-

\footnotetext{
${ }^{1}$ Metni Düzenleyen ve Oynayan: Erdem Şenocak.
} 
Şım kazandırır. Saussure, dilbilimine kazandırdığı yapısalcı yaklaşım tarzıyla kendinden sonraki birçok araştırmacıya ve okula ilham kaynağı olur (Yozgat, 2018: 37). Doğan Aksan, yapısalcılığın Amerika'da çok yankı uyandırdığını özellikle Chomsky ve Chomsky ile aynı paralelde çalışan dilbilimcilerin çabalarıyla 20. yüzyılın ikinci yarısında ortaya atılan Üretken Dilbilgisi Kuramının yapısalcılıktan etkilendiğini bildirir (2006: 18). 20. yüzyılda ortaya çıkan üretken dilbilgisinin farklı bir yönü de cümledeki anlam bileşenini çalışma konusu hâline getirmesidir. Özellikle Chomksy'nin sözdizimi merkezli çalışmaları Katz ve Fodor'un etkisiyle anlam bileşeninin de yer verildiği bir yapıya bürünür.

1950'li yıllardan itibaren Söz Eylem(edim), Metin Dilbilimi/Söylem ve Edimbilim gibi kuramlar cümleyi anlam bileşeni bakımından incelerken bu bileşendeki dil dışı etkenleri de gözlemlemeye başlar. Bahsini açtığımız bu gözlemleme Tamba Mecz tarafından "gelişmeci dönem, karma dönem ve dilsel modeller" dönemi olarak üçe ayrılan (Aksan, 2006: 19) anlambilimin dönemlerinden "dilsel modeller dönemi"ne girer. Dilin dil dışı etkenlerle birlikte incelenmesi dilbilim çalışmalarında yeni bir kulvar oluşturur.

1955 yılında İngiliz filozof ve dilbilimci J. L. Austin Harvard Üniversitesinde William James seminerleri bünyesinde vermiş olduğu derslerde dilin edimselliği düşüncesinden yola çıkarak yeni bir kuramı temellendirmeye çalışır. Gündelik dil çözümlemesi denilen felsefi bir yöntemi temel alarak yapılan derslerde temellendirilmeye çalışılan kuram, "Söz Edimleri Kuramı"dır. Söz Edimi Kuramı, on iki bölüm süren bu ders dizisi sonucunda derse katılan öğrencilerin ve Austin'in tuttukları notlar toparlanarak oluşturulan "Söylemek ve Yapmak" (Austin, 217) adlı eserle düşünce dünyasına sunulur.

Kuram hakkında ayrıntılı çalışmaları olan Levent Aysever, söz edimi teriminde edimin eyleme, sözün ise dile gönderme yaptığını aktarır (2014: 74). Edimin eylem, sözün ise dile gönderme yaptığını esas alan bir kuramın gündelik dili, araştırma öznesi hâline getirmesi kaçınılmazdır. Dilbilim alanında gündelik dilin incelenmeye başlamasının altında ise farklı bir süreç yatar. Gündelik dili çalışma öznesi hâline getiren gündelik dil felsefecileri dili olgular bünyesinde araştıran mantıkçı pozitivistlerden ayrılırlar. Vedat Çelebi, bu ayrılmayı gündelik dil felsefesinin, mantıkçı pozitivistlerin doğrulanabilirlik ilkesine karşı çıkmasından dolayı oluştuğunu, buna karşın gündelik dilcilerin olgusal bildirimler dışındaki cümleleri de kapsayacak bir anlam kuramı oluşturmayı hedeflediğini söyler (2014: 74).

Gündelik dilci yaklaşımın mantıkçı pozitivizmi eleştirmesi ve gündelik dil anlayışının nasıl oluştuğunu belirlemek için Ludwig Wittgeinstein'a ayrı 
bir parantez açmak gerekir. Ahmet Alkayış "Dil Felsefesi Bağlamında Wittgenstein'ın Tractatus Logico-Philosophicus ile Felsefi Soruşturmalar Döneminin Karşılaştırılması" adlı makalesinde filozofun çalışmalarını genel olarak "Tractatus Logico-Philosophicus" ve "Felsefi Soruşturmalar" olarak iki döneme ayırmanın mümkün olduğunu vurgular (2018: 37). Wittgenstein'ın ilk dönem eseri olan Tractatus'ta filozof, dünyanın olgular yoluyla belirlendiğini belirtir ve dünyanın sınırlarını olguların oluşturduğunu vurgular (2013: 15). Ona göre bireyler olguların tasarımlarını kurar. Olguların mantıksal tasarımı ise düşüncedir (2013: 23). Filozof eserinde düşünceyle dili bağlarken düşünceye doğrulanabilir bir kavram olarak bakılması gerektiğini "doğru düşüncelerin toplamı, dünyanın bir tasarımıdır" diyerek (2013: 27) belirtmiş olur. Wittgeinstein Tractatus'ta düşünceleri dile getirebilmeye yarayan ime "cümle-imi" der. Filozofa göre cümle imi de bir olgudur (2013: 29). Dili de bir olgu olarak gören filozof Tractaus'ta, gündelik dilin anlaşılması için yapılan sessiz düzenlemelerin korkunç derecede karmaşık olduğunu belirterek gündelik dille alakalı fikrini de ortaya koymuş olur (2013: 47).

Gündelik dilin araştırma malzemesi hâline gelmesi Wittgenstein'ın ikinci dönem çalışmalarına denk gelir. Filozof "Tractatus" u yazdıktan 31 sene sonra kaleme aldığı "Felsefi Soruşturmalar" kitabında çocukların ana dillerini öğrenme sürecini "dil oyunları” (2006: 16) olarak adlandırır ya da oyun kavramını irdeleyip bu başlı̆ı̆ı içine kart oyunları, top oyunları, olimpiyat oyunları gibi oyun türlerini de dâhil etmesi sonucunda "aile benzerliği” (2006: 47) gibi bir kavramı ortaya atmış olur. Böylece dili sadece olgular bünyesinde gören bir anlayıştan uzaklaşıp ilk dönem çalışmalarıyla kıyasladığımızda daha çok gündelik ve pratik olan bir çizgiye geçer. Bu geçiş dilbilim çalışmalarında ayrı bir kırılmaya zemin hazırlar.

Söz edimleri kuramı, bu kırılmadan beslenen ve gündelik dili çalışma malzemesi hâline getiren bir kuramdır. Yukarıda da belirttiğimiz gibi Austin söz edimleri kuramının nüvesini Harvard Üniversitesinde verdiği derslerde oluşturur. Vedat Çelebi kuramın temsilcisi olan Austin'in gündelik dil felsefesine genel biçimini kazandırdığını ve ilk olarak betimleyici ve edimsel ifadeler arasında ayrım yaptığını söyler (2014: 75). Austin bunu yaparken doğrulanabilir ve hareket bildiren cümleleri birbirinden ayırır. Bu ayrım doğruluk ya da yanlışlık belirten cümleler(betimleyiciler) ve doğruluk ya da yanlışlık değerine sahip olmayan edimlerle ilgili olan bir ayrımdır. Ona göre "istek belirten anlatımlar, emirler, ünlem cümleleri; doğru ya da yanlış olmayan buna karşın günlük yaşantımızda kullandığımız ve kendileriyle birtakım eylemler gerçekleştirdiğimiz söylemlere örnektir (2017: 42-44). 
Austin'in bahsettiği eylemler günlük hayatımızda sürekli gerçekleştirdiğimiz eylemlerdir ve bu eylemler dile getirildiğinde iletişime geçen kişilerin bir "edime" ulaştığı cümleler olurlar. Austin bu cümlelere edimsel cümleler adını verir. Levent Aysever, Austin'in "Söylemek ve Yapmak" adlı eserine yazdığı sunuş bölümünde filozofun derslerini planlarken "bir şey söylemek bir şey yapmaktır" şeklinde özetlenebilecek dilin edimselliği düşüncesiyle ilgili bir kuramı (söz edimi) temellendirdiğini aktarır (2017: 25). Aysever aynı eserde "edimselliğin" bu eserin üzerinde yükseldiği temel düşünce olduğunu vurgular (2017: 29). Dilin edimsel bir işlevi olduğunu bu şekilde belirten Austin'e göre edimlerin gerçekleşmesi ya da başarıya ulaşması yukarıda da belirttiğimiz gibi edimlerin yanlışlanabilir ya da doğrulanabilir olmasına değil, yerinde olup olmamasına bağlıdır.

Konuşan kişinin dile getirdiği edimsel bir cümle ancak belli koşullarda yerinde olabilir diyen (2017: 14) Austin'e göre yerindelik kavramı söz edimleri için anahtar kavramdır. Filozof, yerindelik koşullarını A, B ve C olarak ayırdığı üç ana başlık üzerinden altı kural hâlinde sıraya koyar. A başlığının iki maddesine göre bir edimin yerinde olması için kabul edilmiş belli bir uylaşımsal (kurala bağlı) işlemin olması ve kişilerin iletişim kurulan ortama uygun olan kişiler olması gerekir. Örneğin mecliste oylamaya sunulmayan bir yasa teklifinin meclis başkanı tarafından direkt kabul edilip teklifin yasa olarak ilan edilmesi kurala bağlı (uylaşımsal) olarak gelişen bir işlem değildir. Yasa teklifinin kabul edilmesi ancak ve ancak oylamayla kabul edilebilecek bir işlemdir ve yasa teklifi sunulduğu anda bunları oylayabilecek kişiler milletvekilleridir. Bu işlem gerçekleşirken milletvekilleri yerine başkaları oylamaya katılıp yasa teklifi geçerse meclis başkanının yasa teklifini kabul etmesi yine yerinde olmaz. Çünkü oylamaya katılan kişiler ortama uygun kişiler değildir.

B başlığının iki maddesine göre, işlemi yani konuşmayı gerçekleştiren kişilerin işlemi yaparken bunu doğru ve eksiksiz bir biçimde yerine getirmeleri gerekir. Austin, $\mathrm{C}$ başlığının iki maddesinde ise konuşan kişilerin, edimsel cümleleri söylerken gerçekten bu edimi gerçekleştirecek duygu, düşünce ve yönelimlere sahip olması gerektiğini vurgular. Austin'e göre bu kişiler konuşmanın sonunda dile getirdikleri edimleri gerçekten yapmışlarsa edim yerinde bir edimdir (Searle, 2000: 15) Austin'e göre bu altı kurala uymayan edimlerin hiçbiri yerinde olan edimler değildir.

Görüldüğü gibi Austin bir edimin yerinde olmasını, konuşmayı gerçekleştiren kişiler ile konuşmanın gerçekleştiği ortama yani dil dışı etkenlere de bağlar. Bu aynı zamanda edimsel cümlelerle betimleyici cümleler arasındaki farkın kesin bir şekilde belirlenmesine sebebiyet verir. Ayrıca Aus- 
tin'in yaptığı ilk derste betimleyicileri ve edimselleri ayırması söz edimlerinin adının konmasına ve bu kuramın altyapısının oluşmasına temel hazırlar. Sekizinci derste, dizinin beşinci altıncı ve yedinci derslerinde yapılan edimseller için başka ayırıcı özellikler aranma işleminin başarısız olmasının sonucu olarak yeni bir başlangıç yapılır. Austin bu derste söz edimlerini düzsöz, edimsöz ve etkisöz olarak üçe ayırır (2017: 12-13). Bunlardan düzsöz edimi kesin bir anlamı ve gönderisi olan bir cümlenin dile getirilmesidir. Austin bu edimi seslendirme, dillendirme ve anlamlandırma olarak üç alt edime ayırır (Searle, 2000: 18). Seslendirme edimi, insanın birtakım sesler çıkarma edimidir. Konuştuğumuz zaman kelimelerin kökünde bulunan seslere Austin "seslem" adını verir. Dillendirme edimi ise belli sözcükleri üretme ve bu sözcükleri söylendiği dilin dilbilgisine uygun şekilde tonlayarak söyleme edimiyken anlamlandırma edimi bir dilin içindeki ses bütünlerini belli bir şeyi anlatmaya çalışarak ve göndermede bulunarak üretme edimidir.

Austin, söz edimleri içinde en önemli basamak olan edimsözleri karar belirticiler (verdictives), yaptırıcılar (exercites), yükleyiciler (comissives), davranış belirticiler (behabitives) ve serimleyciler (expositives) olarak beşe ayırır (Searle, 2000: 21). Üçüncü söz edimi ise "etkisöz edimi"dir. Edimsöz bir şey söylerken bir şey yapma ise etkisöz edimi "bir şey söyleyerek bir şey yapmadır." (ya da bir şey söyleyip bir şey yaptırmaktır). Örneğin "X ülkesine savaş ilan ediyorum, askerlerimiz savaşa hazır olsun." diyen bir devlet başkanı bu cümleyi söyleyerek düzsöz edimini gerçekleştirir. Devlet başkanı burada $X$ ülkesi derken savaş açılacak ülkeye göndermede bulunur. Başkan, "ilan ediyorum" cümlesiyle edimsöz edimini yerine getirir. Bunların dışında bu cümle dünya üzerinde savaş başlatacak "etkiye" sahip bir cümledir. Etkisözler bu bakımdan edimsellerin içindeki en "kinetik" olanıdır. Çünkü bu edim, dile getirildiğinde konuşan kişiyi de dinleyen kişiyi de etkisi altına alabilen ve iletişimdeki tüm unsurların hareketlerini yönlendirebilecek bir güce sahiptir. Söz edimlerini bu şekilde sınıflandıran Austin her ne kadar kuramı ilk ortaya atan isim olsa da kuramı geliştiren ve daha da ileriye taşıyan isim Searle olmuştur. Bu bakımdan Searle'e ayrı bir başlık açmamız gerekir.

\section{Searle'e Göre Söz Edimleri}

Her ne kadar söz edimleri kuramını ilk ortaya atan isim Austin olsa da kuramı asıl geliştiren ve ayakları üzerinde durmasını sağlayan kişinin Searle olduğunun altını çizmemiz gerekir. Söz Edimleri Kuramı için böyle bir öneme sahip olan Searle, bir şey söylemenin ya da bir şey söyleyerek bir şey yapmanın içeriğini araştırmak ister. Kuram hakkında bazı noktalarda 
Austin'le hemen hemen aynı çizgide görünen Searle'ün Austin'le farklılaştığı nokta ise düzsöz-edimsöz ayrımının gereksizliği konusundadır.

Searle, Austin'in düzsöz-edimsöz ayırımını "Austin on Locutionary and Illocutionary" başlıklı yazısında değerlendirir ve bu ayrımın yapılmaması gereken bir ayrım olduğunu belirtir (2000: 27). Levent Aysever Searle'ün "Söz Edimleri” kitabında kaleme aldığı sunuş bölümünde, düzsözedimsöz ayrımının, belirli bir anlamla bir cümle dile getirmek ile belirli bir güçle bir cümle dile getirmek arasında yapılan bir ayrım olduğunu ve bu ayrıma göre 'bunu yapacağım' cümlesinin bir söz verme, bir bildirim, bir tehdit, bir uyarı gücü taşıyabileceğini ama bu cümlede 'yapmak' ile anlatılmak istenenin her iletişim ortamında aynı olduğunu belirtir (2000: 27).

Searle, kendi sınıflandırmasını Austin'in düzsöz-edimsöz ayrımına yaptığı itirazlar üzerinden kurgular. Searle'e göre herhangi bir iletişim ortamında kendisine bir gönderimde bulunmak amacıyla dinleyen kişiye bir cümle söyleyen kişi, seslendirme edimi, dillendirme edimi, önerme edimi ve edimsöz edimi gibi edimleri gerçekleştirir (2000: 34). Searle "Söz Edimleri” kitabının “Anlatımlar ve Söz Edimleri” bölümünde söz edimlerini ayırırken şu örneklerden faydalanır: 1. Sam sürekli sigara içer. 2. Sam sürekli sigara içer mi? 3. Sam sürekli sigara iç. 4. Sam keşke sürekli sigara içse (2000: 94). Bu cümleler anlamsal bir kategorileşmeyi de beraberinde getirir. Buna göre kişi ilk cümleyi söylerken bir bildirimde bulunur, ikincisinde bir soru sorulur, üçüncüsünde bir emir verilir, dördüncüsünde ise bir istek dışa vurulur.

Searle bu dört cümle için, cümleler söylenirken cümlelerin hepsinde Sam'e göndermede bulunduğunu ve aynı zamanda bu nesneye sigara içme eylemini yüklediğini belirtip bu örneklerdeki gönderme ile yükleme edimlerini, kesinleme, soru sorma, emir verme gibi edimlerden ayırmak gerektiğini vurgular (2000: 92). Searle, kişinin bu dört cümlenin hangisini söylerse söylesin, sözcükler söylemek (sözceleme edimi), gönderme yapıp yüklemede bulunmak (önerme edimi), önerme bildirmek, soru sormak, emretmek, söz vermek vb. gibi edimlerde bulunduğunu ifade eder (2000: 93).

Sözü geçen üç edimi Austin'in söz edimleri sınıflandırmasına karşı çıkarak oluşturan Searle'ün Austin'le aynı düşündüğü tek söz edim türü ise etkisöz edimleri olurken Searle etkisözleri, edimsöz edimi kavramıyla bağlantılı; edimsöz edimlerini dinleyen kişilerin eylemleri, düşünceleri, inançları üzerindeki sonuçlarını gösteren bir edim olarak belirtir (2000: 93).

Sonuç olarak Searle'ün söz edimlerini sınıflandırırken sözcelem edimi, önerme edimi, edimsöz edimi ve etkisöz edimi ayrımına gittiğini belirtebi- 
liriz. Buna ek olarak Levent Aysever'in Searle'ün ayrımında dikkat edilmesi gerekilen söz edimi türünün edimsöz edimi olduğunu aktardığını da (2000: 34) vurgulamamı gerekir. Searle edimsözleri kesinleyiciler, yönelticiler, yükleyiciler, dışavurucular ve bildirgeler olmak üzere beşe ayırır (2000: 49).

Edimsözlerin içeriğini Searle'ün tasnifine göre aktarırken incelediğimiz romanlardan cümle örneklerini vermenin konunun daha iyi anlaşılması hususunda olumlu bir katkı yapacağını düşünüyoruz. Kuyucaklı Yusuf'da Yusuf ile işçi kadın arasında geçen şu diyalog kesinleyici sınıfına girer: "... Ne diye ağanı bıraktın da buraya geldi, yenge?", "Dövdüler beni, ağam!" (Ali, 2015: 35). Diyalogda görüldüğü gibi işçi kadın Yusuf'a neden oraya geldiği hakkında bilgi verip açıklama yapar. Bu aynı zamanda işçi kadını söylediği sözün doğruluğu noktasında bir sorumluluğun altına sokar. Kesinleyici sınıfına giren edimsöz ereği bu örnekteki gibi kişiyi dile getirdiği önermenin doğru olduğu konusunda yükümlülük altına sokar. Bu edime örnek olarak ileri sürmek, iddia etmek, bildirmek, yadsımak, savunmak, bilgi vermek, aktarmak gibi cümle türleri örnek verilebilir (Searle, 2000. 49-50). Yine aynı romanda işçi kadının kızına seslenerek "Haydi Kübra, doğrul azıcık, Yusuf Ağa geldi!” (Ali, 2015: 37) demesiyle kadın kızına bir şey yaptırmak ister. Yöneltici edimsöz edimleri ise tıpkı bu örnekteki gibi dinleyen kişiye bir şey yaptırmaya yarayan edimlerdir. Sormak, emretmek, buyurmak, rica etmek, yalvarmak, dua etmek, yasaklamak bu edime örnek olarak gösterilir (Searle, 2000: 50). Üçüncü edimsöz ise yükleyicilerdir. Bu edimsöz türü Searle'ün Austin'in edimsöz edimi tasnifiyle örtüşen bir edimsözdür. Aylak Adam'ın 21. sayfasında Sadık karakterinin Sami'ye verdiği "Elbet sana da bakacam..." cümlesi Sadık'ı gelecekte yerine getirmesi gereken bir sorumluluğa iter. Bu bakımdan cümle yükleyici edimsöze örnektir ki bu edimsöz kişiyi gelecekte bir yükümlülüğe sokar. Söz vermek, tehdit etmek, yemin etmek, reddetmek, teklif etmek, güvence vermek yükleyicilere örnektir (Searle, 2000: 50). Dışavurucular ise kişinin içindeki ruhsal durumu aktaran edimlerdir. Tehlikeli Oyunlar'da geçen "...özür dilerim: bir yanımız çok ısınmıştı.” (Atay, 2018: 21) Hikmet'in içindeki ruhsal durum dışa vurulmuştur. Bu edimin örnekleri ise teşekkür etmek, tebrik etmek, özür dilemek, taziyede bulunmak, esef etmek olarak verilebilir. Son edimsöz türü olan bildirgeler ise dünyayı değiştirme amacında olan edimlerdir. Bu edimlere istifa etmek, işten kovmak, atamak örnekleri verilir (Searle, 2000: 50-51). "... Alay falan değil, dedi, dört gün önce bir sokak levhasında 'iki Öksüzler Sokağı' adını okuduğum zaman kendi kendimi bir işe atadım.” (Atılgan, 2017: 19). Örnekte görüldüğü gibi konuşucu atama yaptığını belirterek dünyada bir değiş̧im yapmaktadır. 
Söz Edimleri Kuramı dilbiliminde yeni bir sayfa açılmasına sebep olurken dilin en önemli yazınsal yaratısı olan edebiyat metinlerinin incelenmesinde de yeni bir yol açar. Edimsel cümleler ile edebî cümlelerin aynı paralelde değerlendirilip değerlendirilmeyeceği Derrida'nın “edebî sözcelemlerin dilin gündelik ve standart kullanımının üzerine asalakça) tutunmuş bir kullanım türü olduğunu” (Büyüktuncay, 2014: 96) savunan Austin ve kuramı geliştiren Searle'e yaptığı eleştiriler sonucunda belirlenir. Derrida edebi edimsellere asalak olarak bakan Austin'e (yukarıda değindiğimiz) edimlerin bağlam ve yinelenebilirlik özellikleri üzerinden eleştiri yapar. Derrida'ya göre edimsel cümleler içindeki anlamı kaybetmeden alıntılanıp başka bağlamlara taşınabilir (Büyüktuncay; 2014: 99). Bu bakımdan anlam tek olsa da edimsel söz sınırsız bir bağlam zincirine girebilir. Günlük hayatta iletişim kuran insanların konuşmasının ardından anlamın konuşucuların niyetinden bağımsızlaşabilmesi durumu üretim süreci biten bir edebî yaratı için de aynıdır. Kısacası bağlam sınırlandırılabilecek bir olgu değildir ve her zaman yenileştirilebilir.

Derrida'nın Austin'e karşı çıktığı bir başka konu ise edimsellerin yinelenebilirlik kavramı üzerine olur. Örneğin bir kişinin Müslüman olabilmesi için kelime-i şahadet içindeki sözcükleri yinelemesi gerekir, bu şekilde dine girme işlemi gerçekleşmiş olur. Derrida ise bu yineleme işlemini sadece örnekteki gibi ciddi söylemler için geçerli olmadığını belirtir. Ona göre tüm dilsel göstergeler alıntılamak, tekrarlamak ya da çarpıtılmak suretiyle yinelenebilir (Büyüktuncay, 2014: 100). Özetle hem dilbilimi hem de edebiyat metinlerini incelemeleri açısından değişik bir pencere açan Söz Edimleri Kuramı ülkemizde birçok araştırmaya konu olmuştur. ${ }^{2}$ Bu araştırmaların önemli bir özelliği kuramın üzerinden edebî ürünlerin incelenmesidir. Kuramın edimlerle betimleyici ifadeleri net bir çizgide ayrıştırması ve dildeki edimleri tasniflemesi nedeniyle dilin edebî yaratıları olan roman, hikâye hatta şiir gibi edebî ürünleri Söz Edimleri Kuramı başlı̆ı altında incelemek bu türler hakkında geçmişte yapılan metin incelemelerine nazaran daha farklı sonuçlar ortaya çıkartabilir.

\section{Sodom ve Gomore, Kuyucaklı Yusuf, Aylak Adam, Tehlikeli Oyunlar ve Kırmızı Saçlı Kadın Kitaplarındaki Edimsözlerin Varlığı Işı̆̆ında Roman Dilinin Sinemaya Yaklaşması}

Diğer sanat dalları düşünüldüğünde, sinema, tarih sahnesine daha geç çıkmış olduğundan "yedinci sanat" olarak adlandırılır. En son ortaya

\footnotetext{
${ }^{2}$ Söz edimleri konusunda yapılan çalışmalara örnekler şunlardır: (Hirik, 2019; Polat, 2011; Çelebi, 2014; Gökmen ve Çağlayan, 2011; Akşehirli, 2011; Aysever, 2013; Say, 2019; Hirik, 2018; Dilek, 2007).
} 
çıkan sanat dalı olmasından dolayı, kendinden önce ortaya çıkan ve kültür dünyasında kök salmış resim, edebiyat, müzik ve tiyatronun etkisine girer ya da etkiler ve adını saydığımız dallarla sürekli iletişimde olur. Hatta Bazin, sinemanın diğer sanatların reenkarnasyonu olarak ortaya çıktığını söyler (2000: 67). Sinemanın edebiyatla olan ilişkisinde vurgulanması gereken ana husus edebiyatın kurgusal söylem noktasında sinemaya kaynaklık etmesidir. Rene Wellek bu konuda, sinemanın kendine özgü bir dil oluştururken edebiyattan tema ve konu üzerinden yararlandığını ve edebiyatın sinemaya hazırlanacak senaryoya temel olan metin bakımından malzeme verdiğini aktarır (1983: 43). Bunun örnekleri olarak günümüzde hem Türkiye'de hem de dünyada edebî üründen uyarlama birçok filmin ve dizinin çekildiğini görüyoruz. Edebiyat sinemayı bu yönde etkilerken sinemanın da edebiyata etkisi kaçınılmazdır. Sinemanın romanı etkilemesi hem "sinema izleyen kitap okuyucusunun değişen beklentileri" hem de sinemaya ayak uyduran roman kurgusu üzerinden olur. Yüzyıllar boyunca, herhangi bir olayın kurgusunu kitap cümlelerinden takip eden okuyucu, gelişen imkânlarla birlikte kurguyu hareketli bir düzlemde (sinemada) takip etmesiyle birlikte okuyucu-izleyiciye dönüşür. Burada üzerinde durulması gereken konu, edebî metinlerdeki betimleme unsurunun sinemanın ortaya çıkmasıyla birlikte değişmesidir. 19.yüzyılda henüz sinemanın gelişmemiş olmasının bir etkisi olarak belirtebileceğimiz uzun betimlemeli romanlar yazılır.

Zeynep Çetin "Bir Anlatı Formu Olan Romanın Sinemaya Uyarlanması" adlı tez çalışmasında Zola'nın "Doktor Pascal” romanında yazarın bir bahçeyi 15 sayfa boyunca betimlendiğini belirtir. (1999: 210). Buna karşın 20. yüzyıl romancısı ve okuyucusu için durumun değiştiğini aktaran Çetin'e göre Malraux, Steinbeck, Hemingway, ilya Ehrenburg gibi romancıların dile sığınmadığını bunun yerine sinemanın görsel imkânlarından faydalandığını ve okurların bu yazarların romanlarını okurken kitabı adeta "gördüklerini" belirtir (1999: 211). Sinemanın edebiyatı etkilemesine dair diğer bir örneği de roman yazarının sinema anlatımından etkilenmesi üzerinden verebiliriz. Yazar, sinemadan etkilenerek edebî metindeki olayın oluş sırasını bozar. Bu yapı son dönem edebî metinlerinde sürekli olarak okuyucunun karşısına çıkan kurgusal bir yapıdır.

"Postmodernizmin Romana Yansıması: Yeni Roman" makalesinde Zeynep Çetin, James Joyce'un sinemadaki birbiriyle alakasız görünen parçaları yan yana koymaya benzer bir anlatım yarattığını aktarırken Ulys ses'in bu anlatıma örnek olarak verileceğini bildirir (2001: 155). Çetin, sinema tarzı anlatımla Ulysses arasındaki bu benzerliği okuyucunun romanı 
istediği yerden başlayarak yeni bir sıralamaya koyması üzerinden tespit eder. Ulysses'da kırılan zaman, romanın bölümlerine sirayet etmiş, başı ve sonu olmayan, istenildiği yerden başlanacak bir kitap kurgusu okuyucunun eline geçmiştir.

Romanda mekân ve zaman kavramları deyince akla hiç şüphesiz kronotop kavramı gelmektedir ki bu da sinemasal anlatımı roman anlatımıyla birleştiren bir başka unsurdur. Mustafa Sözen "Bakhtin'in Romanında Kronotop Kavramı ve Sinema" makalesinde Bahktin'in Türkçeye mekânzaman olarak çevrilen kronotop (kronos [zaman]-topos [yer]) terimini Einstein'dan ödünç aldığını aktarır (2018: 93). Sözen kronotop kavramının romanda geçen temel anlatısal olayları örgütleyen bir merkez olduğunu ve romandaki anlatımın mekân-zamanda düğümlendiğini söyler. Sözen'in makalesinden hareketle Bahktin'in kronotop kavramını edebiyatın sanatsal olarak ifadeleştirdiği zaman ve mekân ilişkilerinin içkin bağlantıııı̆ına kronotop adını verdiğini aktarmamız gerekir. Mekân-zaman anlamında kullanılan kronotop kavramı romanda yazarın kurduğu dünyayla direkt olarak ilgilidir. Peki sinema ile romanı yakınlaştıran bir diğer unsurun kronotop olduğu sonucuna nereden vardık? Sözen yukarıda adını verdiğimiz makalesinde sinemanın zaman ve mekânı düzenleme sanatı olduğunu aktarır. Aynı zamanda sinema görselliğe dayandığı için yer- olay ve zamanı aynı zamanda dokuduğu ve bu sebepten sinemadaki kronotopun edebî metnin anlatımındaki başat unsur olduğunu bildirir (2018: 97). Edebî ürünü kaynak alan sinema edebî metindeki mekân-zaman olgusunu "yeniden dokur" ve özellikle uyarlama eserlerde bu öğeleri görselleştirerek izleyiciye sunar.

Görüldüğü gibi edebiyat ve sinemanın arasında her daim canlı ve tek taraflı olmayan bir etkileşim söz konusudur. Bu etkileşim, edebiyat ve sinemanın anlatım kurgularını ve okuyucu-izleyicinin tercihlerini değiştirecek kadar güçlü bir etkileşimdir. Zeynep Çetin'in yukarıda bahsettiğimiz çalışması üzerinden kültür hayatına sinema girmiş 21.yüzyıl okuyucusunun "eseri okurken görmek istemesi" okurun yazar seçiminde etkili olabilecek bir unsurdur. Ülkemizde, günümüzde en çok okunan yazarlara şöyle bir baktığımızda Orhan Pamuk, Sabahattin Ali, Oğuz Atay, Yusuf Atılgan, gibi isimleri ilk sıralarda görüyoruz. Bunun nedenini sadece bu yazarların (Sabahattin Ali hâriç) modernist ya da postmodernist olması mıdır? ${ }^{3}$ Evet, Türkçe romanın sinema diline yaklaştığı, sinema söyleminden yararlandığını ya da sinemanın romandan yararlandığı bilinen bir gerçekliktir. Bu

\footnotetext{
${ }^{3}$ Adı geçen yazarların modernist ya da postmodernist yönlerinin incelendiği eser olarak bk. (Ecevit, 2016).
} 
tespitin, metinlerarasılık, montaj, kolaj, brikolaj gibi terimlere dayandırılmasının ya da romanlarda kullanılan dilin geçmiş zamandan şimdiki zamana kaydığının söylenmesinin, roman dilinin sinema diline yaklaştığının bir dayanağı olarak belirtilmesi yanlış değildir fakat bu tespitin geliştirilmesi gerekmektedir.

Bize göre edimsözler romana okunabilir olması dışında yeni bir fonksiyon katar. Romandaki kurgu edimsözlerin etkisiyle okuyucunun elinde artık "izlenebilen" bir metne dönüşür. Dolayısıyla insanların arasındaki iletişimde kullandığı hareket, iş ve oluş fiillerinin edimlerini tasnif eden edimsözlerin edebi metinde yer alması -bizce- okuyucuya romanı ya da hikâyeyi gözünde hareketli kesitler olarak canlandırmasına yardımcı olur. Bu hususlar üzerinde yukarıda belirttiğimiz eserlerdeki cümleleri Searle'ün edimsöz tasnifine göre inceledik. İncelememizin sonucunda ilk baskısı 1928 yılında yapılan ve 295 sayfa olan Sodom ve Gomore'nin edimsöz sayısı 922 çıkarken ilk baskısı 1937 yılında yapılan ve toplam 220 sayfa olan Kuyucaklı Yusuf'ta bu sayının 1116 olduğunu gördük. Bunun dışında 1959 yılında ilk baskısı yapılan ve 190 sayfa olan Aylak Adam romanında ise edimsözler 1345 adet çıkmıştır. Incelediğimiz beş roman içerisinde edimsözlerin en fazla çıktığı eser Tehlikeli Oyunlar'dır (2018). Atay'ın romanında 2345 adet edimsöz çıkarken 190 sayfalık Kırmızı Saçlı Kadın romanında toplam edimsöz sayısı 820'dir. Eserlerdeki edimsözlerin istatistiksel dağılımı şu şekildedir.

\section{Edimsözlerin Eserlere Göre İstatiksel Dağılımı}

Kırmızı Saçlı Kadın Romanının Edimsöz İstatistikleri

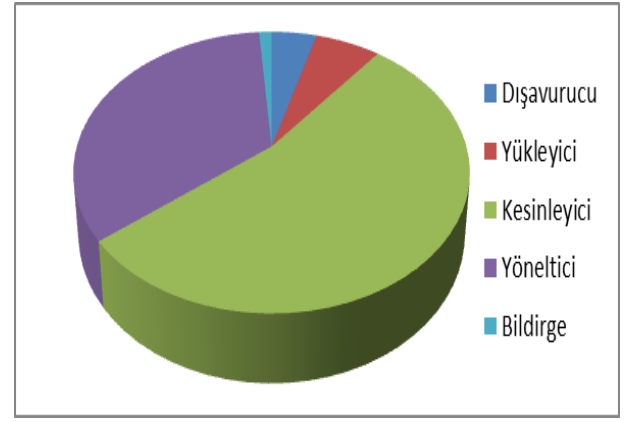

$\begin{array}{lll}\text { Dışavurucu } & 36 & 4 \% \\ \text { Yükleyici } & 52 & 6 \% \\ \text { Kesinleyici } & 440 & 54 \% \\ \text { Yöneltici } & 282 & 35,00 \% \\ \text { Bildirge } & 10 & 1,00 \% \\ \text { TOPLAM } & 820 & \end{array}$


Tehlikeli Oyunlar Romanının Edimsöz İstatistikleri

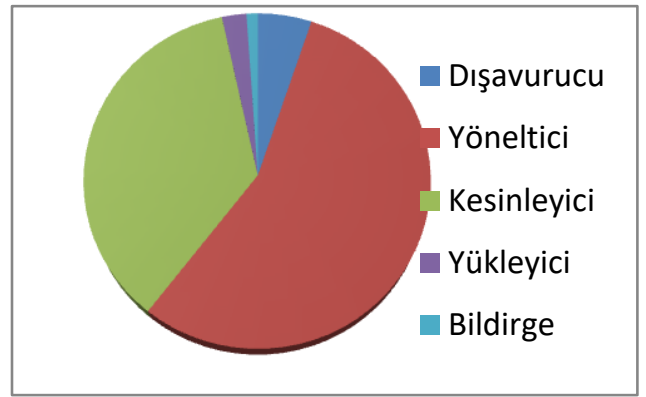

$\begin{array}{ccc}\text { Dışavurucu } & 134 & 5 \% \\ \text { Yöneltici } & 1439 & 55 \% \\ \text { Kesinleyici } & 937 & 45 \% \\ \text { Yükleyici } & 61 & 3 \% \\ \text { Bildirge } & 28 & 1,00 \% \\ \text { TOPLAM } & 2599 & \end{array}$

Aylak Adam Romanının Edimsöz İstatistikleri

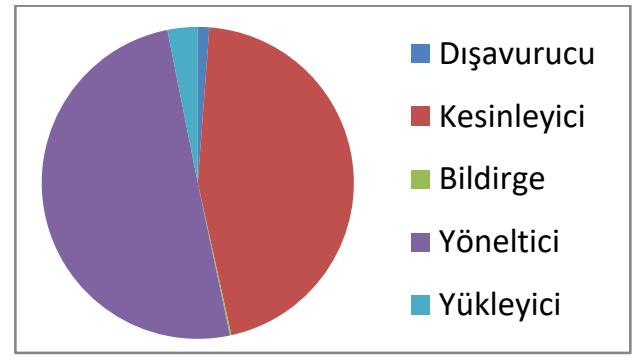

$\begin{array}{lll}\text { Dışavurucu } & 16 & 1 \% \\ \text { Kesinleyici } & 610 & 45 \% \\ \text { Bildirge } & 2 & 1,00 \% \\ \text { Yöneltici } & 675 & 50 \% \\ \text { Yükleyici } & 42 & 3 \% \\ \text { TOPLAM } & 1345 & \end{array}$

Sodom ve Gomore Romanının Edimsöz İstatistikleri

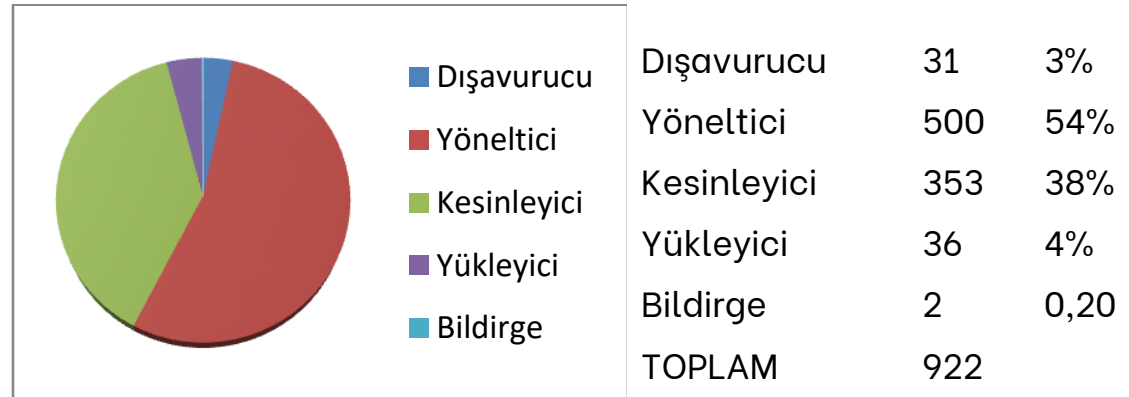

Kuyucaklı Yusuf Romanın Edimsöz istatistikleri

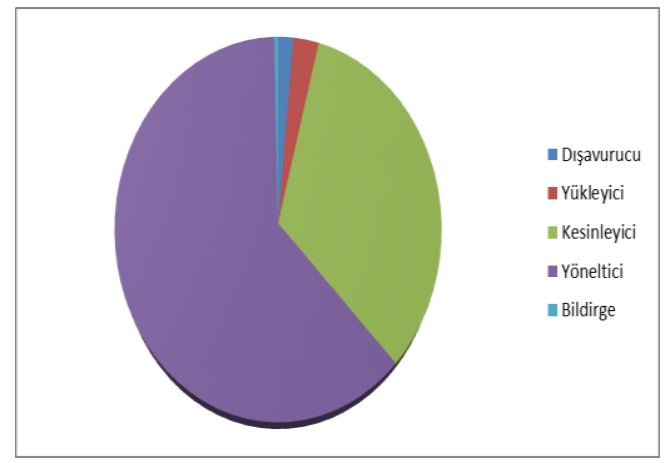

$\begin{array}{ccc}\text { Dışavurucu } & 16 & 1 \% \\ \text { Yükleyici } & 26 & 2 \% \\ \text { Kesinleyici } & 390 & 35 \% \\ \text { Yöneltici } & 680 & 61 \% \\ \text { Bildirge } & 4 & 0,30 \% \\ & & \\ \text { TOPLAM } & 1116\end{array}$


Beş Romanın Edimsözlerinin Genel Analizi

\begin{tabular}{|c|c|c|c|c|c|c|}
\hline & KES'NLEYIC| & YÜKLEVYCI & DISSAVURUCU & YÖNELTICI & BILDIRGE & \\
\hline Sodom ve Gomore & $38 \%$ & $3 \%$ & $4 \%$ & $54 \%$ & $1 \%$ & \\
\hline Kuyucakkı Yusat & $35 \%$ & $2 \%$ & $1 \%$ & $61 \%$ & $1 \%$ & \\
\hline Tehlikeli Oyunlar" & $45 \%$ & $3 \%$ & $5 \%$ & $55 \%$ & $1 \%$ & \\
\hline Aylak Adam & $42 \%$ & $4 \%$ & $1 \%$ & $51 \%$ & & \\
\hline Kırmizl SaçI Kadin & $55 \%$ & $4 \%$ & $5 \%$ & $35 \%$ & $1 \%$ & \\
\hline \multicolumn{7}{|l|}{$70 \%$} \\
\hline \multicolumn{7}{|c|}{ KESINLEYICI } \\
\hline \multicolumn{7}{|c|}{ YÜKLEYICi } \\
\hline \multicolumn{7}{|c|}{ - } \\
\hline $30 \%$ & & & & 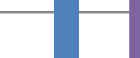 & & \\
\hline $20 \%$ & & & & & YÖNE & ElTiCi \\
\hline $10 \%$ & & & & & - BiLDip & RGE \\
\hline 0\% & (I) & suffehlikeli C & Aylak A & mKırmızı Saçl & çlı Kadın & \\
\hline
\end{tabular}

ilk olarak şunu belirtmemiz gerekir ki beş eserin dördünde edimsöz sayısı açısından kronolojik bir yükselme tespit ettik. Kırmızı Saçlı Kadın da ise aynı yükselişten söz edemiyoruz. Fakat 295 sayfalık Sodom ve Gomore'de 920 adet edimsöz çıkarken 195 sayfalık Kırmızı Saçlı Kadın romanında 820 edimsözün çıkması bizlere bu eserde de yoğun bir edimsöz varlığının olduğuna işaret eder. Buradan hareketle çalışmamızda incelediğimiz romanların genelinde edimsöz yoğunluklarının arttığının altını bir kez daha çizmemiz gerekir.

Searle'ün tasnifine göre yaptığımız edimsöz araştırmasında bütün romanlarda sayıları en fazla çıkan edimsözlerin kesinleyiciler ve yönelticiler olduğunu gördük. Bu bakımdan bu iki edimsöz türüne ayrı bir parantez açmamız gerekir. Kesinleyiciler (assertives) bir şeyin söylediği gibi olduğu konusunda konuşan kişiyi yükümlülük altına sokan edimlerdir. Burada önemli olan durum dünyanın söze uygun olması durumudur. ${ }^{4}$ Yönelticiler

\footnotetext{
${ }^{4}$ Sözün dünyaya uygunluğu ya da dünyanın söze uygunluğu konusunu, Levent Aysever, Söz Edimleri kitabına yazdığı sunuş bölümünde şu şekilde açıklar: Karısının verdiği Fasulye, yağ, salam, ekmek gibi malzemeleri almaya giden bir adamla onu takip eden dedektif örneğinde, alışveriş yapan adamın elindeki listeyle dedektifin elindeki liste aynıdır. Alışveriş yapan adamın elindeki listenin amacı dünyayı söze uydurmaktır. Buna karşılık dedektifin elindeki listeyi adamın eylemlerine uydurması gerekir. Bu bakımdan dedektif sözü dünyaya uydurmaya çalışmaktadır. Aralarındaki fark eğer adam siparişe uymayan bir malzeme alırsa bunu düzeltebilir fakat dedektif bunu yapamaz. Ayrıntılı bilgi için bk. (Searle, 2000: 42).
} 
(directives) ise söylenen sözün dinleyen kişiye bir şey yaptırmaya çalışan edimlerdir. Yönelticilerde konuşan kişi herhangi bir isteğini dışavurur. Bu edimde ise dünya söze uydurulur. İncelediğimiz romanlarda sayısı yüksek çıkan kesinleyici ve yönelticilerin tanımsal içeriğinde "dünyayı söze uyduran" ya da sözün dünyaya uygun olması hususlarının bulunması, bize edimsözlerin (incelediğimiz romanlar özelinde) yazarın kendi dünyasını yaratırken bilerek ya da bilmeyerek başvurduğu unsurlar olduğunu gösteriyor. Kesinleyici ve yönelticilerin sayılarının yorumlarını yukarıda belirttiğimiz şekilde yapmakla beraber bu edimsözlerle ilgili birkaç noktaya daha değinmemiz gerekir. Kesinleyici edimsöz türünün örnekleri, ileri sürmek, iddia etmek, bildirmek, yadsımak, savunmak, bilgi vermek, aktarmak, ısrar etmek, varsaymak, tahmin etmektir. Romanları incelerken en fazla karşımıza çıkan kesinleyici türlerinin -en çoktan en aza doğru- aktarım, tahmin, bilgi vermek ve bildirmek edimleri olduğunu belirtmemiz gerekir. Searle'ün tasnifinde kesinleyici ve yöneltici dışında yükleyici, dışavurucu ve bildirge de vardır. Tekrar hatırlatacak olursak yükleyiciler söz vermek, tehdit etmek, yemin etmek, reddetmek gibi konuşan kişiyi gelecekte bir eylem yaratma konusunda yükümlülük altına sokan edimlerdir. Bu edimsöz türü ise romanlarda en fazla çıkan üçüncü edim olmuştur. Yükleyiciler özelinde ise dünya söze uydurulur.

Dışavurucu ve bildirge ise romanlarımızda en az çıkan iki edimsözdür. Dışavurucular bireyin yaşadığı ruhsal hâli dışa vurmasıyla oluşan bir edimsözdür. Dışavurucu edimsözlerin teşekkür etmek, tebrik etmek vb. örnekleri vardır ki bu iki örnekte teşekkür eden ya da tebrik eden kişi sevinç ve minnet duygularını dışa vurmuş olur. Bildirgeler ise dünyada bir değişiklik yaratma ereğinde olan edimsözlerdir. (istifa etmek, işten çıkarmak vb.) Bu iki edimin az çıkmasının nedeni aslında tezimizdeki iddiamızı güçlendirecek cinstendir. Özellikle katıksız bir dışavurucu edime ulaşabileceğimiz metnin roman değil senaryo olduğunu düşünüyoruz. Kurgusu gereği senaryo, edimsözlerin daha yoğun bulunabileceği bir metin türüdür. Çünkü senaryo metninde karakterlerin oyununu gerçekleştirdiği mekândan, duygu durumlarına kadar her şey kayıt altında olmak zorundadır. Oyuncunun gerçekçi bir rol yapabilmesi için bu es geçilemeyecek bir noktadır. Bu bakımdan bu iki edimsözü senaryo edimsözü olarak tasnif etmemizin olumlu olacağını düşünüyoruz. Diğer üç edimin "edebî edim" olduğunu söylememiz için daha geniş bir araştırma yapmamız gerekir fakat kesinleyici, yöneltici ve yükleyici edimlerinin cümle örneklerine baktığımızda diğer kitaplar da bulunabilecek edimler olduğunu da göz ardı etmememiz gerekir. 
Özellikle Tehlikeli Oyunlar'da dışavurucu ve bildirgenin diğer romanlara göre fazla çıkması ise bir başka sonucu gözler önüne seriyor. Eserde yazarın yaptığı şey yaşadığımız hayattaki tarih, mekân ve gerçeklik gibi kavramları eserin evreniyle birleştirerek yepyeni bir dünya ortaya koymasıdır. Atay bu eserinde roman özelliği ağır basan bir senaryo kaleme almıştır. Atay'ın eserde kullandığı dili senaryoya yaklaştıran unsurun eserinde kullandığı 134 adet dışavurucu olduğunu düşünüyoruz. Bu sayı incelediğimiz eserler arasında çıkan en yüksek dışavurucu sayısıdır. Bu bakımdan Atay'ın hem roman edimlerini hem de senaryo edimlerini birleştirebilen bir yazar olduğunu görüyoruz. Bu durum aslında başka bir sorunun cevabını da beraberinde getiriyor.

"21. Yüzyıl okuyucusu”na Sodom ve Gomore'nin dili mi daha yakın geliyor yoksa Tehlikeli Oyunlar'ın dili mi? Bunun nedenini sorguladığımızda (çalışmamı özelinde) "romanı izlemek isteyen okurun" beklentisinin devreye girdiğini düşünüyoruz. Atay, eserindeki yoğun edimsöz kullanımıyla okuyucunun konuyu daha iyi "yaşamasına" sebebiyet veriyor. Bu bakımdan günümüz okurunun tercihinin Sodom ve Gomore'den yana değil Tehlikeli Oyunlar'dan yana olmasının bir nedeni de bu beklenti oluyor.

Sinemanın edebiyattan aldığı malzemeler düşünüldüğünde, bu beş romanda en çok yönelticilerin ve kesinleyicilerin bulunmasının, roman evreninin okuyucunun gözünde kristalize olmasına ve görselleşmesine yardımcı olduğu düşüncesindeyiz. Eserlerde tespit ettiğimiz edebî edimler anlatıma hareket kazandırarak kelimelere, cümlelere ve paragraflara "görsel bir vücut" dokuyor, "karakterlerin edimleriyle" vücut buldukça maddileşen kitabın konusu kendi sınırlarını aşıyor ve kendine yeni bir mecra arıyor. Biz bu yeni mecranın sinema olduğunu düşünüyoruz. Burada söylemeye çalıştığımız bir kitabın sinema ya da diziye uyarlanması için mutlaka belirli bir edimsöz oranına sahip olma kuralı değildir. Elbette ki kitaplar edimsöz sayısına bakılmaksızın senaryolaştırılabilir, iddiamız edimsözlerin romanı sinemaya yaklaştırdığıdır. Diğer yandan günümüzde, dönemlerindeki yazarların bir adım önüne çıkarak okunan Oğuz Atay'ın, Sabahattin Ali'nin, Yusuf Atılgan'ın çok fazla rağbet görmesinin nedenlerinden birinin de yoğun edimsöz kullanımı olduğunu düşünüyoruz. Çünkü yeni bir okur kitlesiyle karşı karşıyayız. "21.yüzyıl okuru” olarak adlandırabileceğimiz bu kitle çok büyük teknolojik gelişmelere şahit olmuştur. Özellikle sinemanın gelişimi kitap okuyucusunun yönelimlerine yön vermiştir. Kolay iletişim ve üst düzey görsellik (sanal gerçeklik gözlükleri vs.) çağında yaşayan 21. yüzyıl okuyucusunun romandan beklentisi artık sadece roman evrenini okumak değil "roman evrenini okurken izlemektir". Yuka- 
rıda Zeynep Çetin'in yaptığı çalışmayı referans gösterirken okuyucunun Malraux, Steinbeck, Hemingway, ilya Ehrenburg gibi yazarların kitaplarını okurken kitabı âdeta gördüklerini belirtmiştik. Bunun nedeni ise yeni nesil okuyucunun sinemayı görmesi ve sinemanın etkisiyle kitaplardaki betimleyici cümlelerin azalmasıydı. Betimleyici cümlelerin azalması sonucunda oluşan yeni roman diline betimleyicilerle edimleri ayıran Söz Edimleri Kuramı penceresinden bakmanın ve bu bakışı sinema-edebiyat ilişkisi içinde değerlendirmenin bahsettiğimiz yeni okuyucu kitlesinin romandan beklentilerini ve süreç içerisinde değişen roman kurgusunun özelliklerini anlamakgibi önemli bir pozisyondadır. Edimsöz sayılarını incelediğimiz romanlardaki yazarların (özellikle Sabahattin Ali, Oğuz Atay ve Yusuf Atılgan) edimsözlerin katkısı ile döneminden farklı bir üslup tutturup böylece bahsettiğimiz bu okur kitlesinin beklentilerini karşılayabilecek bir boyuta erişebildiklerini düşünüyoruz.

Kitapta anlatılan olayları okurken görmek ya da karakterleri birebir izlemek sadece betimlemeyle açıklanacak bir durum değildir. Romanda, yapılmış, gerçekleşmiş, iş, amel olarak tanımlanan edimlerin yoğun olarak geçmesi okuyucuyu betimlemenin bile üstünde olan bir boyuta taşır. Bu boyut, romanın konusunu sadece okuyarak değil izleyerek yaşamakla ilgili olan bir boyuttur.

\section{(...) "Duracak zaman değil. İşin çaresine bakmalı!}

Çaresine bakılacak tarafı mı var? (...) Üç senede, beş senede, elbet ödemeye çalışacağız." (Ali, 2015: 49).

Diyalogdaki ilk cümlede geçen "işinin çaresine bakmalı" ifadesinde karşıdaki kişiye bir şey yaptırma ereğinde olan yöneltici edim, ikinci cümlede ise soru sorularak yöneltici, "elbet ödemeye çalışacağız" ifadesiyle de kişiyi gelecek hakkında bir yükümlüğe sokan yükleyici bir edim yerine getirilmiştir.

Cümlenin başına "buyurgan bir sesle" ifadesi konularak okuyucuya karakterin sözü söylerken ne yapmak istediği ve konuşucunun potansiyel ruh hâli hakkında daha ayrıntılı bilgi veren bir cümle yazılabilir ama buradaki yöneltici edim, okuyucuya sözü söyleyen ve dinleyen karakterin, içinde bulunduğu "ciddi durumu" hayal dünyasında canlandırma fırsatı verir. Ayrıca son cümledeki yükleyici edim sayesinde, okuyucu güvence veren karakteri zihninde sorumluluk hisseden bir kişi olarak çizebilir. Bu noktada roman söylemi sinemaya yaklaşır. Ciddi bir konu konuşan ve konuşuculardan birinin sorumluluk duygusuna sahip olduğu anlaşılan iki kişiyi zihinde canlandıran edimler okuyucuya diyalogdaki karakterleri âdeta izlettirir. 
"Tekaüt olduktan sonra kanaatlerim biraz değişmişti ama gene de hangi resim sergisine gitsem, koşar ressamı tebrik ederdim; bütün piyeslerden sonra alkışlamaktan ellerim acırdı." (Atay, 2018: 280). Bu cümlede ise tebrik etme ile yerine getirilen edim dışavurucu edim olur. Dışavurucu edimde sözü söyleyen kişinin ruhsal durumu dışa vurulmuş olur. Cümledeki tebrik etme ifadesi tebrik eden insanın sevincini dışa vuran bir ifade olur. Kişi tebrik ederek sevinme duygusunu dışa vurur. Dolayısıyla okuyucunun gözünde alkışlarken sevinen bir karakter canlanmış olur. Buradaki canlanma durumu betimleme yapar gibi durağan bir hâlde değil karakterin edimine bağlı olarak gelişen dinamik bir canlanmadır. Bu dinamizm, okuyucuya kitabı okurken kitap kurgusunu gözünde sürekli hareket ettirmesini sağlayan bir dinamizmdir. İncelediğimiz iki romandan verdiğimiz örnekler ışığında Austin ve Searle tarafından betimleyici cümlelerden ayrımı kesin bir çizgiyle ayrılmış edimlerin, sinema ile tanışmış okuyucuya romanı okurken kurguyu durağan bir şekilde değil tıpkı sinemadaki gibi akıcı bir şekilde "yaşamasına" fırsat verdiğini çalışmamız özelinde tespit ettiğimizi düşünüyoruz.

\section{Sonuç}

Dünden bugüne insanlığın oluşturduğu kültür ve sanata bağlı tüm alanlar türümüzün düşünsel gelişiminde bizlere yol gösterici unsurlar olmuştur. Edebiyat ve sinema özelinde düşündüğümüzde bu alanların hem entelektüel hem de bilişsel yönlerimizi en çok besleyen alanlar olduğu sonucunu çıkarımlayabiliriz. Kültürel hayatımızı şekillendiren bu iki alanın birbiriyle iletişimlerini çeşitli yönlerden incelemek, toplumsal psikoloji ve sosyoloji disiplinlerine de hizmet edecek boyuttadır. Makalemizde her şeyden önce bu iki dalın birbiriyle iletişiminin dil üzerinden olduğunu bu yüzden dilbilimsel bir yöntemle bu ilişkiye bakmanın gerekliliğini vurgulamaya çalıştık.

Çalışmamızda defaatle 21. yüzyıl okuyucusunun bir kitaptan beklentisi sinemanın gelişimiyle birlikte farklılaştığını belirttik. Okuyucu roman evrenini okumanın yanında artık onu izlemek de istemektedir. Bu istemle birlikte hareket eden okuyucunun yazar seçimi de belirlenmiş olur. Aylak Adam, Kuyucaklı Yusuf ve Tehlikeli Oyunlar gibi eserlerin günümüzde daha büyük bir ilgiyle okunmasının nedeninin yukarıda belirttiğimiz "yeni okuyucu tipinin kitaptan beklentileri” olduğunu düşünüyoruz. Sinemanın aksiyona yani edime dayalı bir dili olduğu kabulünden incelediğimiz eserlere bakarsak eserlerdeki yoğun edim kullanımının hem okuyucunun eserlere olan ilgisini arttırdığını hem de edimsel sözlerin (bu eserler özelinde) roman dilini sinemaya yaklaştırdığını tespit edebiliyoruz. Günümüzde çok 
okunan kitaplar göz önüne alındığında Aylak Adam, Kuyucaklı Yusuf, Tehlikeli Oyunlar ya da Kırmızı Saçlı Kadın gibi eserlerin bir adım öne çıkmasının bir nedeni de bu kitaplardaki "edimsöz varlığı olabilir mi?" Bizce bu sorunun cevabı bu araştırma özelinde "evet”tir. Buradan hareketle söz edimi varlığının edebî ürünlerde tespit edilmesinin sinema ve edebiyat ilişkisini inceleyen, okuyucunun değişen beklentilerini tespit etmeye çalışan, edebî metine dilbilimsel bir pencereden bakmaya çalışan tüm araştırmacılara farklı bir yol göstereceği kanaatindeyiz.

\section{Kaynakça}

Aksan, Doğan (2006). Anlambilim, Anlambilim Konuları ve Türkçenin Anlambilimi. Ankara: Engin Yayınevi.

Aksan, Doğan (2009). Her Yönüyle Dil: Ana Çizgileriyle Dilbilim. Ankara: Türk Dili Kurumu Yayınları.

Akşehirli, Soner (2011). "Söz Edimleri Kuramı Açısından Kurgusal Anlatı Metinlerinde Söz Aktarımı”. Turkish Studies, 6(2): 143-162.

Ali, Sabahattin (2015). Kuyucaklı Yusuf. İstanbul: Yapı Kredi Yayınları.

Alkayış, Ahmet. (2018). “Dil Felsefesi Bağlamında Wittgenstein'ın Tracta-

tus Logico- Philosophicus ile Felsefi Soruşturmalar Döneminin Karşılaştırılması". Uluslararası Anadolu Sosyal Bilimler Dergisi, 2(1): 35-47. Atay, Oğuz (2018). Tehlikeli Oyunlar. İstanbul: iletişim Yayınları.

Atılgan, Yusuf (2017). Aylak Adam. İstanbul: Can Yayınları.

Austin, J. L. (2017). Söylemek ve Yapmak 2. (Çev. R. L. Aysever). İstanbul: Metis Yayınları.

Aysever, Levent (2013). "Bir Söz Edimi Olarak Yargı Edimi”. Dokuz Eylül Üniversitesi, Edebiyat Fakültesi Dergisi, 2(3).

Bazin, Andre (2000). Sinema Nedir? İstanbul: İzdüşüm Yayınları.

Büyüktuncay, Mehmet (2014). "Söz Edimleri Kuramı ve Edebiyat: Anlam, Bağlam, Yinelenebilirlik". International Journal Of Language Academy, 2(1): 93-105.

Can, Aytekin; Uğurlu, Faruk (2010). "Gölgesizler Filmi ve Edebiyat Sinema Ilişkisi Üzerine”. Selçuk Üniversitesi Iletişim Fakültesi Akademik Dergisi, 77-83.

Çelebi, Vedat (2014). "Gündelik Dil Felsefesi ve Austin'in Söz Edimleri Kuramı". Beytulhikme An International of Philosophy, 4(1): 74-89.

Çetin, Zeynep (1999). Bir Anlatı Formu Olan Romanın Sinemaya Uyarlanması. Doktora Tezi. İstanbul: Marmara Üniversitesi Sosyal Bilimler Enstitüsü. 
Çetin, Zeynep (2001). "Roman-Sinema Etkileşimi: Yeni Roman ve Yeni Dalga”. Marmara Üniversitesi Iletişim Dergisi, 143-165.

De Saussure, F. (1998). Genel Dilbilim Dersleri. (Çev. B. Vardar). İstanbul: Multilingual.

Dilek, Fidan (2007). Türkçe Ezgi Örüntüsünde Duygu Durum ve Söz Edimi Görünümü. Doktora Tezi. Ankara: Ankara Üniversitesi Sosyal Bilimler Enstitüsü.

Ecevit, Yıldız (2016). Türk Romanında Postmodernist Açılımlar. İstanbul: iletişim Yayınları.

Eisenstein, S. M. (1999). Sinema Dersleri. İstanbul: Öteki Yayınevi.

Gökmen, Seda Dilber; Çağlayan, Nilay (2011). "Türkçe Derslerinde Söz Edimlerinin Öğretimi Üzerine Bir Değerlendirme”. Dil Dergisi, 154.

Hirik, Erkan (2018). "Söz Edimleri Kuramı Bağlamında AtasözleriDeyimlerde Toplum-Topluluk Adları ve Duygu Değerleri”. Motif Akademi Halkbilimi Dergisi, 24: 158-177.

Hirik, Seçil (2019). "Dede Korkut Hikâyelerinde Söz Edimi Yapıları". Manas Sosyal Araştırmalar Dergisi, 8(1): 751-768.

James, Monaco (2000). Bir Film Nasıl Okunur? İstanbul: Oğlak Yayınları.

Karaosmanoğlu, Yakup Kadri (2017). Sodom ve Gomore. İstanbul: iletişim Yayınları .

Orhan, Pamuk (2016). Kırmızı Saçlı Kadın. İstanbul: Yapı Kredi Yayınları.

Polat, Yusuf (2011). "Yabancı Dil Öğretimi Kitaplarında Söz Edimi Öğretimi”. Dil Dergisi, 153.

Say, Gamze (2019). "Ay Işığında Şamata Adlı Tiyatro Metninde Söz Edim Incelemesi”. Nevşehir Hacı Bektaş Veli Üniversitesi SBE Dergisi, 9(1): 274-286.

Searle, John R. (2000). Söz Edimleri. Ankara: Ayraç Yayınları.

Sözen, M. Fadıl (2018). "Bahktın'ın Romanında Kronotop Kavramı ve Sinema". Akdeniz sanat, 1.

Wellek, Rene (1983). Edebiyat Biliminin Temelleri. Ankara: Kültür ve Turizm Bakanlığı Yayını.

Wittgeinstein, Ludwig (2006). Felsefi Soruşturmalar. İstanbul: Totem Yayıncılık.

Wittgeinstein, Ludwig (2013). Tractatus Logico-Philosophicus. İstanbul: Metis Yayınları.

Yozgat, Umut (2018). Dilbilim Kuramları. İstanbul: Ithaki Yayınları. 
Yüce, Tuncay (2005). "Sinema ve Edebiyat Türleri Arasında Görülen Etkileşimler”. ZKÜ Sosyal Bilimler Dergisi, 67-74. 